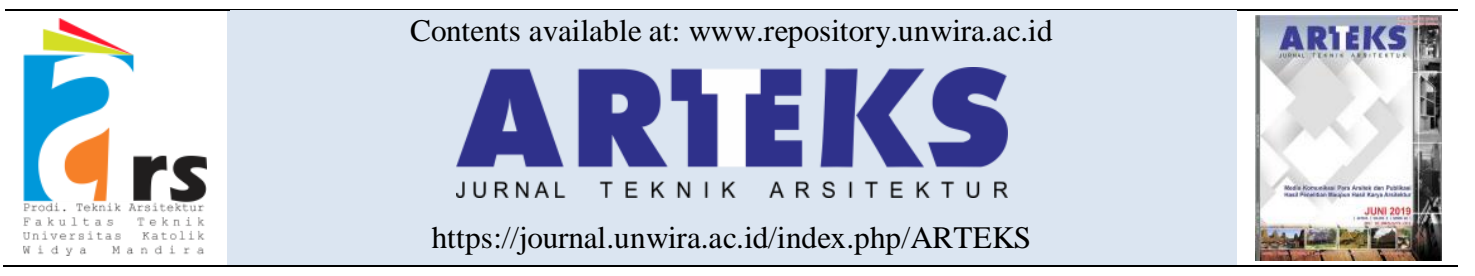

Editorial paper

doi: $10.30822 /$ arteks.v5i3.665

\title{
Architecture as a relation of doing and being
}

\section{Reginaldo Christophori Lake}

\author{
Chairman of the Editorial Board \\ Editor in-Chief ARTEKS : Jurnal Teknik Arsitektur \\ Department of Architecture, Faculty of Engineering, Universitas Katolik Widya \\ Mandira, Indonesia \\ Email: reginaldolake@unwira.ac.id
}

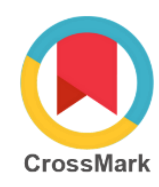

ARTEKS : Jurnal Teknik Arsitektur, volume 5, issue 3, December 2020 presents the fifteen on the conception of research results, which defined architecture as an inseparable coin related to "doing" and "being". This architectural expression is Michelangelo's (1475-1564) story associated with the design of a Pieta statue (1498-1499), which later became an "immortal" masterpiece. Michelangelo stared at the marble slab for months when asked to design it without carrying out any activity. This attitude surprised the owner, namely the Catholic Church, as the task-giver (PEN@ Katolik 2020). Michelangelo contemplated for months by staring at the slab to receive inspiration to "speak" through shape, grain, texture, and color (Frampton 2001; Thiss-Evensen 1987; Arinto 2018; Pallasmaa 1994). The act of waiting for the marble to "speak" takes months as a form of presence and representation of the Pieta statue to beyond the transcendental layer of consciousness (Gomez 1994; Sastrosasmito 2020).

Michelangelo's story is an excellent example of the distinction between "doing" such as "carving" a slab of marble and "being," which is associated with "contemplating" on its use to make a beautiful statue. A method was proposed by Edmun Husserl (1900-1901) to determine the real experience of the observer (Undi 2013). The encounter of materials was studied in climate responsive construction types (Indrawan, et al; Wardhani, et al.; Qurix and Doshu); and nature as a concept of sustainable materials (Nugroho; Imran, et al.). The concept of "doing" and "being" are like two sides of the same coin that are needed in architectural engineering to portray the right existence (Salura 2010). Obtaining a beautiful statue of Pieta is impossible when the Michaelangelo stops at "being" with the inability to have a soul when it only does "doing" (Salura 2001). The "doing" and "being" carried out by Michelangelo are in line with Merleau-Ponty's thinking, as well as the relationship between the subject and object (Undi 2013).

Architecture is a "marker" of human culture development, which has a relatively high level of legacy preservation (Koentjaraningrat 1993; Oliver 1975); Its existence is traced to thousands of years ago, with the inception of vernacular architecture (research by Setiawan et al.; Sari et al.; Tobing et al.; Lapenangga et al.). Architecture is currently associated with the timeline of clear tidal and developments in climate adaptation and socio-culture (presented by Adiyanto). Cultured in architecture always becomes a tug and a cycle between "doing" and "being"; "Container" and "content"; "Body" and "soul" (NorbergSchulz 2000), as well as part of the contemporary sustainability ideas concept (research by Estika, et al.; Saputra, et al.). Therefore, architecture is not "inanimate objects" instead "living things" due to its ability to tell and express ideas through forms, figures, symbols, and identities to the observer (Salura 2012; Salura 2018; Lake et al. 2020). Architectural works speak to humans through a unique language (Zucker and Norberg-Schulz 1970; Widodo 2019) gasped through their correlation and awareness with the environment and reality (research by Dwisusanto and Hermawan; Susanto, et al; Tantarto and Hertoery).

The implication of the fifteen articles in the ARTEKS : Jurnal Teknik Arsitektur, volume 5 issue 3, December 2020 is that architecture is a relation and not a subject, object, doing, or being.

Copyright (C2020 Reginaldo Christophori Lake. This is an open access article distributed the Creative Commons Attribution-NonCommercial-ShareAlike 4.0 International License 


\section{Referensi}

Arinto, Fransiscus Xaverius Eddy. 2018. 'Pelestarian Arsitektur Berdasarkan Architectural Architypes Melalui Metode Grafis'. ARTEKS: Jurnal Teknik Arsitektur 3 (1): 29-36. https://doi.org/10.30822/arteks.v3i1.52.

Frampton, Kenneth. 2001. Studies in Tectonic Culture: The Poetics of Construction in Nineteenth and Twentieth Century Architecture. Cambridge: MIT Press.

Gomez, Alberto Perez. 1994. 'The Space of Architecture: Meaning as Presence and Representation'. In Questions of Perception -Phenomenology of Architecture, edited by Steven Holl, Special is. Tokyo: A+U Publishing.

Koentjaraningrat. 1993. Manusia Dan Kebudayaan Di Indonesia. 14th ed. Jakarta: Djambatan.

Lake, Reginaldo Christophori, Fransiscus X. Eddy Arinto, Yohanes Djarot Purbadi, Yohanes Basuki Dwisusanto, Elvis Albertus Bin Toni, and Robertus Mas Rayawulan. 2020. 'Architecture Expression: Synthesized Architectural Expressions in Mayor's Office Building of Kupang City'. Local Wisdom : Jurnal Ilmiah Kajian Kearifan Lokal 12 (2). https://doi.org/10.26905/lw.v12i2.4302.

Norberg-Schulz, Christian. 2000. Architecture: Presence, Language and Place. Skira Library of Architecture. Milan, Switzerland: Skira.

Oliver, Paul. 1975. Shelter, Sign \& Symbol. London: Barrie \& Jenkins.

Pallasmaa, Juahni. 1994. 'An Architecture of the Seven Senses'. In Questions of Perception Phenomenology of Architecture, edited by Steven Holl, Special is. Tokyo: A+U Publishing.

PEN@ Katolik. 2020. 'Tujuh Fakta Kecil Yang Tidak Banyak Diketahui Tentang Patung Pieta Karya Michelangelo'. Penakatolik.Com. 2020. https://penakatolik.com/2020/01/18/tujuh-fakta-kecil-yangtidak-banyak-diketahui-tentang-patung-pieta-karya-michelangelo/.

Salura, Purnama. 2001. Ber-Arsitektur; Membuat, Menggunakan, Mengalami, Memahami. Bandung: Architecture \& Communication.

- 2010. Arsitektur Yang Membodohkan. 1st ed. Bandung: CSS Publishing.

—. 2012. 'Sintesis Elemen Arsitektur Lokal Dengan Non Lokal, Studi Kasus: Gedung Sate Di Bandung, Gedung UPS Di Tegal'. Bandung.

- 2018. 'Anatomy of Architecture Based on the Creation of Space for Activity'. International Journal of Engineering \& Technology 7 (2.14): 205-7.

Sastrosasmito, Sudaryono. 2020. 'Arsitektur Sebagai Realitas Kemanusiaan (Dari Keseharian Sampai Kesadaran Transendental)'. ARTEKS: Jurnal Teknik Arsitektur 5 (2): 141-42. https://doi.org/10.30822/arteks.v5i2.531.

Thiss-Evensen, Thomas. 1987. Archetypes in Architecture. Oxford: Oxford University Press.

Undi, Gunawan. 2013. 'Fenomenologi Arsitektur; Konsep, Sejarah Dan Gagasannya'. Nalars 12 (1): 43-59. https://jurnal.umj.ac.id/index.php/nalars/article/view/569.

Widodo, Johannes. 2019. 'Human, Nature, And Architecture'. ARTEKS : Jurnal Teknik Arsitektur 3 (2): 145-48. https://doi.org/10.30822/arteks.v3i2.65.

Zucker, Paul, and Christian Norberg-Schulz. 1970. 'Intentions in Architecture'. The Journal of Aesthetics and Art Criticism. https://doi.org/10.2307/429522. 